\title{
Economic Efficiency Assessment of Autonomous Wind/Diesel/Hydrogen Systems in Russia
}

\author{
O. V. Marchenko and S. V. Solomin \\ Energy Systems Institute of Russian Academy of Sciences, 130 Lermontov Street, Irkutsk 664033, Russia \\ Correspondence should be addressed to O. V. Marchenko; marchenko@isem.sei.irk.ru
}

Received 19 December 2012; Accepted 13 March 2013

Academic Editor: Onder Ozgener

Copyright ( 2013 O. V. Marchenko and S. V. Solomin. This is an open access article distributed under the Creative Commons Attribution License, which permits unrestricted use, distribution, and reproduction in any medium, provided the original work is properly cited.

\begin{abstract}
The economic efficiency of harnessing wind energy in the autonomous power systems of Russia is analyzed. Wind turbines are shown to be competitive for many considered variants (groups of consumers, placement areas, and climatic and meteorological conditions). The authors study the possibility of storing energy in the form of hydrogen in the autonomous wind/diesel/hydrogen power systems that include wind turbines, diesel generator, electrolyzer, hydrogen tank, and fuel cells. The paper presents the zones of economic efficiency of the system (set of parameters that provide its competitiveness) depending on load, fuel price, and longterm average annual wind speed. At low wind speed and low price of fuel, it is reasonable to use only diesel generator to supply power to consumers. When the fuel price and wind speed increase, first it becomes more economical to use a wind-diesel system and then wind turbines with a hydrogen system. In the latter case, according to the optimization results, diesel generator is excluded from the system.
\end{abstract}

\section{Introduction}

In the recent years, the energy policy of many countries has been aimed at increasing the share of renewable energy sources (RES) in the total energy production. In Russia, the share of RES (without large hydropower plants) in the electricity production does not exceed $1 \%$. However, the "Energy Strategy of Russia for the period up to 2030" (approved by the Russian Government) suggests that, in 20 years, this share may increase up to $4.5 \%$.

Providing a substantial environmental effect (decrease in the emissions from energy sector), RES can often be economically efficient and competitive with the energy sources based on fossil fuel [1-7]. It is expected that, in the nearest and, moreover, distant future, the role of RES in Russian and world energy industry will essentially increase due to the improvement of characteristics and a projected rise in the fossil fuel price [8-12].

It is reasonable to use RES primarily in small autonomous (decentralized) power systems located in remote hard-toreach areas, where the price of imported fossil fuel is very high. Russian zones of decentralized power supply that do not have any modern electrical networks and large energy sources occupy about $70 \%$ of the country and are situated mostly in the Far North. The Far North is represented by a number of regions in the European part of the country (Murmansk and Arkhangelsk regions, the Republic of Karelia, and the Republic of Komi), Siberia (the north of Tyumen Region and Krasnoyarsk Territory), and the Far East (Yakutia, Chukotka, Magadan, Kamchatka, and Sakhalin regions). These territories have significant reserves of gold, platinum, diamonds, tin, lead, and other mineral resources.

In total, about 1400 small settlements with a population of approximately 20 million people are located in decentralized power supply zones of Russia [3, 4]. About 7 thousand diesel power plants operate here. The majority of them have a high degree of physical deterioration and low efficiency. The cost of electricity produced by new diesel generators usually exceeds 25-30 cent/kWh (US dollar for economic assessment is used throughout the paper), and in the remotest regions with old diesel generators, it exceeds $50-70$ cent $/ \mathrm{kWh}$.

Decentralized systems of power supply are characterized by the following features: 
(i) settlements are spread throughout large scarcely populated territories;

(ii) electric load of consumers in each settlement does not exceed 1-3 MW;

(iii) transport infrastructure is underdeveloped;

(iv) the main electricity source is diesel power plants;

(v) diesel power plants use expensive diesel fuel, which usually costs more than $\$ 800-\$ 1000 /$ toe [4].

Therefore, the introduction of renewables to increase the cost effectiveness of power supply is an urgent problem for these systems. One of the most effective types of RES is wind turbines $[1,4]$.

In 2011, the total installed capacity of all wind turbines operating in the world accounted for $238 \mathrm{GW}$ (increased by $20 \%$ as compared to 2010) [13]. Wind turbines generate about $2.5 \%$ of the total electricity production in the world. As opposed to both many developed and developing countries, Russia uses wind energy very little. The installed capacity of wind turbines is about $20 \mathrm{MW}$, and the rate of wind energy development was less than 10\% in 2010 and 2011 [14]. The share of wind turbines in the total electricity production in Russia is negligible (less than $0.01 \%$ ).

Meanwhile, the potential for the wind energy development in Russia is really great. Russia has the longest shoreline in the world, abundant treeless flatlands, and large water areas of inner rivers, lakes, and seas, which represent the most favorable sites for wind turbines.

The main advantages of wind turbines are as follows:

(i) no harmful emissions in the process of electricity production;

(ii) relative cheapness of generated electricity (3$5 \mathrm{cent} / \mathrm{kWh}$ for the best turbines under good wind conditions);

(iii) possibility of significantly saving on fossil fuel in the course of operation in an autonomous power system.

At the same time, wind turbines have a flaw. This is an unsteady electricity generation (depending on changes in wind speed). Therefore, wind turbines are used in combination with energy sources that operate under the controlled conditions and supply power to the load when power generated by wind turbines is insufficient or during their downtime. Besides, power systems with wind turbines include energy storage devices.

The research aims to study the economic efficiency of harnessing wind energy in Russia for a wide range of parameters (fossil fuel price, climatic and meteorological conditions, power and load curve of consumers, and current and prospective technical and economic indices of the power system components). First of all, the authors consider the most promising wind/diesel systems, including the systems that produce, store, and use hydrogen in fuel cells (wind/diesel/hydrogen systems).

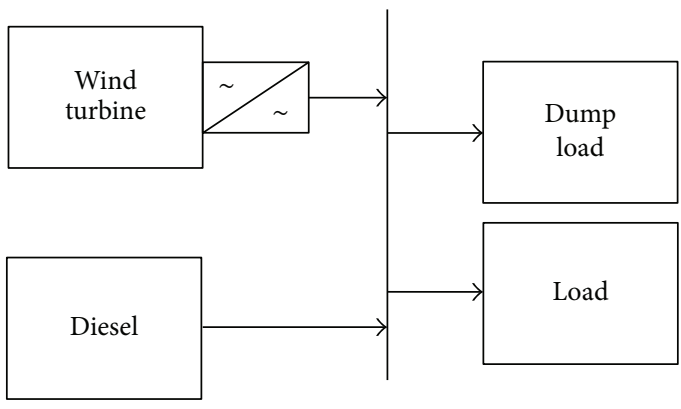

Figure 1: Wind/diesel system.

\section{Variants of Harnessing Wind Energy}

The authors consider three variants of harnessing wind energy in the autonomous power systems to supply power to consumers.

In the first variant, wind turbines are included in the wind/diesel system (Figure 1). The capacity of a diesel generator is chosen so that it provides uninterrupted power supply to consumers even in the case of wind turbine downtime during calms. In the periods of strong wind, however, some amount of power generated from wind turbines turns out to be redundant and is diverted to the dump load.

The other two variants allow for the storage of energy in the form of hydrogen produced by electrolysis and electrochemically transformed into electric energy. Under certain conditions, the introduction of a subsystem for production, storage, and use of hydrogen for energy purposes into the wind/diesel system can decrease the diesel fuel consumption (or even exclude the diesel generator from the system) and reduce the costs of electricity production.

The second variant considers a simplified (linear) scheme in which electric energy or hydrogen sequentially passes through the system components; diesel generator is excluded (Figure 2). Here, it is assumed that the volume of hydrogen produced is sufficient to have constant electric power of fuel cells. This means that the combination of wind turbines with stochastic power generation and a hydrogen system (electrolyzer, hydrogen tank, and fuel cells) allows us to obtain a new property of the energy source, that is, constant generation (by additional costs). If the installed capacity of an electrolyzer is lower than the capacity of wind turbines, some amount of the generated electricity may turn out to be redundant and will be diverted to the dump load. The use of excess electricity in heat supply (as well as the heat generated by fuel cells) was not considered in this paper. In fact, the utilization of this heat can prove to be economical and increase the efficiency of the whole system [1]. However, this will require the introduction of additional components into the scheme (heat exchangers, pipelines, pumps, etc.) and more detailed consideration of consumer specific features, which goes beyond the scope of this paper.

In the third variant (Figure 3), the autonomous power system includes diesel units, one or several wind turbines, electrolyzer, hydrogen tank, fuel cells, and electricity consumers with their load curve. It is assumed that the diesel 


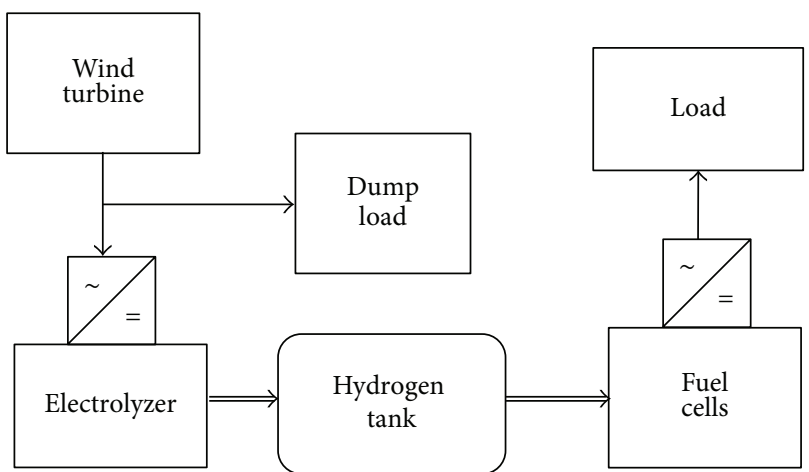

FIGURE 2: Wind/hydrogen system.

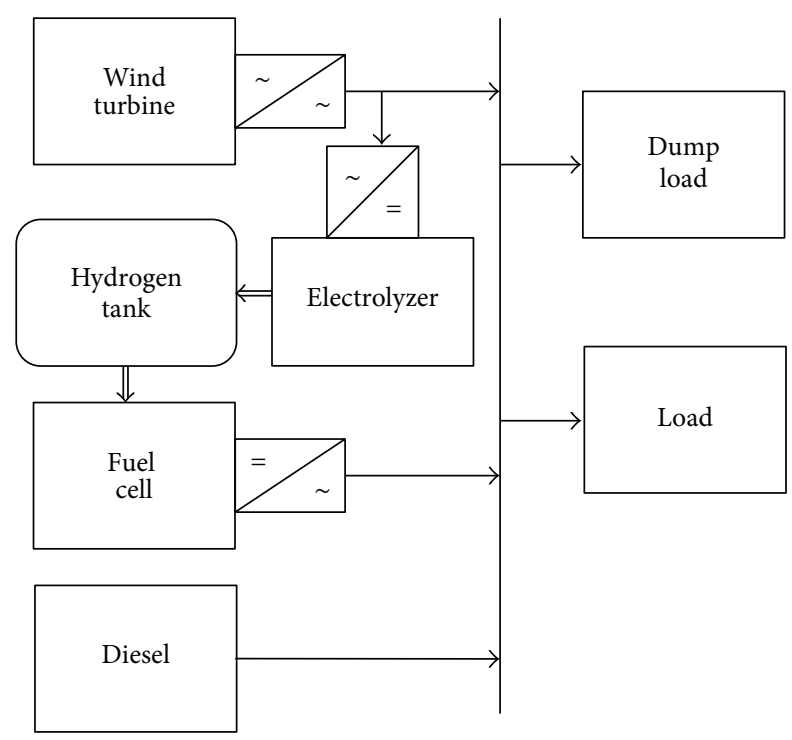

FIgURE 3: Wind/diesel/hydrogen system.

power plant, wind turbines, electrolyzer, and fuel cells are provided with all the devices required to control the network. Wind turbines supply electricity directly to the consumers with changing load. If this electricity is insufficient, diesel generator and fuel cells can operate simultaneously. The excess power from wind turbines is consumed by the electrolyzer (if the hydrogen tank is not fully filled with hydrogen) or absorbed by the dump load.

\section{Calculation Method}

As is known [8], the cost effectiveness of an investment project is characterized by the net present value (NPV); that is, the total income obtained during the project period $T$ reduced to the initial time point:

$$
\mathrm{NPV}=\int_{0}^{T} E(\tau) \exp (-\sigma \tau) d \tau
$$

where $E(\tau)$ is the cash flow; $\sigma=\ln (1+d)$; $d$ is the annual discount rate.
For many energy sources, including RES, we can use the following simplified model, which describes their construction and operation: construction takes a short time and requires capital investments $K$. Right after the construction, the energy source starts to operate under nominal conditions with average annual costs $Z$ and electricity supply $Q$ at price p.

Then,

$$
\begin{aligned}
\mathrm{NPV} & =-K+\int_{0}^{T}\left(p_{e} \mathrm{Q}-Z\right) \exp (-\sigma \tau) d \tau \\
& =\frac{1}{\sigma}[1-\exp (-\sigma T)]\left(p_{e} \mathrm{Q}-Z\right)-K,
\end{aligned}
$$

where $p_{e}$ is the electricity price.

Among the compared alternative variants, the best one will provide the maximum NPV.

Costs $Z$ can be divided into two parts: constant components (that do not depend on the volume of electricity production) and variable components that consist mainly of fuel costs:

$$
Z=\mu K+p_{f} b Q
$$

where $\mu$ is the specific constant costs (share of investments); $p_{f}$ is the fuel price; $b$ is the specific fuel consumption (a value inversely proportional to the efficiency).

Then, from (1)-(3), we obtain

$$
\mathrm{NPV}=\frac{1}{\sigma}[1-\exp (-\sigma T)] Q\left(p_{e}-S\right),
$$

where

$$
S=\frac{\mathrm{CRF} \cdot K+Z}{Q}=\frac{k}{h} \mathrm{CRF}+\frac{k}{h} \mu+\frac{p_{f}}{\theta \cdot \eta}
$$

is the electricity cost. Here, we use the following notations: $k$ is the specific capital investments (per power unit); $h=\mathrm{CF} \cdot H$ is the annual number of utilization hours (CF is the capacity factor, $H=8760 \mathrm{~h}$ /year); $\mathrm{CRF}=\sigma /[1-\exp (-\sigma T)]$ is the capital recovery factor; $\theta=11.6 \cdot 10^{3} \mathrm{kWh} /$ toe is the energy equivalent.

According to (4), the electricity cost represents the minimum price, at which the project is cost effective (net present value equals zero), and the best variant $(\mathrm{NPV}=\max )$ should be chosen on the basis of the criterion of minimum electricity cost (5).

The terms in the right-hand side of equality (5) represent the capital, O\&M, and fuel components of the electricity cost, respectively. Fuel price for the energy sources based on energy of the wind, sun, or rivers equals zero $\left(p_{f}=0\right)$, while the value of capacity factor CF significantly depends on meteorological conditions $[1,3,4,15,16]$.

To assess the competitiveness of RES, we should compare the cost of energy produced on their basis with the cost of energy from competing energy sources. In the case, where RES operate under uncontrolled (stochastic) conditions and require full capacity backup, the cost of energy produced by them should be compared not to the total cost but to the 
fuel component of the cost of energy produced by the energy source on fossil fuel $[3,4]$.

This comparison makes it possible to assess the competitiveness of RES (Figure 1) at the first approximation and exclude inefficient variants from further consideration. By analogy, we can make preliminary estimation of the hydrogen and electricity cost (Figure 2) that can be compared to the cost of diesel fuel and electricity from diesel generator. Such estimation proves to be very illustrative and narrows the feasibility region of parameters to be used in calculations for the autonomous power system, taking into account the interaction between its components.

More accurate calculations require that the system effects related to power flows between system components and its storage have to be taken into account. Optimization of the autonomous power system structure and operation (Figure 3) is reduced to solving the problem: find the objective function (electricity cost) minimum

$$
S=\frac{1}{Q}\left[\sum_{i} \mathrm{CRF}_{i} K_{i}+Z_{i}\right] \longrightarrow \min ,
$$

subject to

$$
\begin{aligned}
& P_{\mathrm{DG}}(t)+P_{\mathrm{WT}}(t)+P_{\mathrm{FC}}(t)=L(t)+U(t) \\
& 0 \leq P_{i}(t) \leq P_{i \max } \\
& U(t) \geq 0 \\
& P_{\mathrm{WT}}(t)=P_{\mathrm{WT} \max } f(v) \\
& P_{\mathrm{FC}}(t) \leq \frac{P_{\mathrm{HT}}^{*}(t) \eta_{\mathrm{HT}} \eta_{\mathrm{FC}}}{\Delta t} \\
& P_{\mathrm{EL}}(t)=\min \left(U(t),\left(\frac{P_{\mathrm{HT} \max }^{*}-P_{\mathrm{HT}}^{*}(t)}{\left(\eta_{\mathrm{EL}} \Delta t\right)}\right)\right) \\
& P_{\mathrm{HT}}^{*}(t)=P_{\mathrm{HT}}^{*}(t-\Delta t)+\left[P_{\mathrm{EL}}(t) \eta_{\mathrm{EL}}-\frac{P_{\mathrm{FC}}(t)}{\left(\eta_{\mathrm{FC}} \eta_{\mathrm{HT}}\right)}\right] \Delta t
\end{aligned}
$$

The following notation is used: $P$ is the power of energy source; $P^{*}$ is the energy equivalent of hydrogen in hydrogen tank; $t$ is the time; $L$ is the load; $U$ is the power surplus; $f(v)$ is the wind turbine power curve; $\Delta t$ is the time step; indices: $i$ is the type of energy source (DG is the diesel generator, WT is the wind turbine, EL is the electrolyzer, HT is the hydrogen tank, and FC are the fuel cells); max and min are the maximum and minimum values.

Equation (7) is the power balance at the time point $t ;(8)$ is the power constraints; (9) is the condition of shortage-free power supply; (10) is the dependence of wind turbine power on wind speed (random value); (11) is the constraint on the power of fuel cells with respect to hydrogen reserve; (12) is the constraint on the power of electrolyzer with respect to power surplus and available capacity in the hydrogen tank; (13) is the hydrogen balance in the hydrogen tank.

To solve system (6)-(13), the algorithm described in [7] was used. Continuous time functions were replaced with sets of discrete values with the step of 1 hour. Wind speed was modeled in the form of random processes in terms of the alternating periods of low and high wind speeds. This is essential for the systems with energy storage systems and, in this case, for the determination of optimal capacity of the hydrogen tank.

At the first stage, when the installed capacities of energy sources and the hydrogen tank capacity are given, the operating conditions are optimized at each time point in accordance with the criterion of minimum fuel costs. The electric load (7) is first covered by energy from wind turbines, then by the energy stored in the hydrogen tank, and finally by the energy from diesel generator. The excess energy from wind turbines is sent to electrolyzer for the production of hydrogen.

At the second stage after the calculation of operating conditions on the entire time interval from $t=0$ to $t=T$, the installed capacities of energy sources and the hydrogen tank capacity are optimized according to criterion (6) subject to constraints (8) and (9).

\section{Initial Data}

The factors that determine the economic efficiency of using wind turbines and hydrogen system in addition to the diesel power plant (or instead of it) in the autonomous power systems are

(i) wind speed,

(ii) diesel fuel price,

(iii) maximum power and degree of load unevenness,

(iv) technical and economic indices of power plants.

The most important energy characteristic of the wind is its long-term average annual speed $V$ measured at a height of a weather vane (about $10 \mathrm{~m}$ ). Figure 4 presents the distribution of this characteristic across the territory of Russia. The zones of low (up to $4 \mathrm{~m} / \mathrm{s}$ ), medium ( $4-6 \mathrm{~m} / \mathrm{s}$ ), and high (more than $6 \mathrm{~m} / \mathrm{s}$ ) wind speeds are highlighted. Average wind speed reaches its maximum on the seacoasts and decreases in the continental areas.

In the European part of the country, annual average wind speed is $2-4 \mathrm{~m} / \mathrm{s}$, and on the coasts of the Arctic Ocean and the Baltic Sea and in some regions of the North Caucasus and Volga region, it reaches $5-6 \mathrm{~m} / \mathrm{s}$. The highest wind speed (more than $7 \mathrm{~m} / \mathrm{s}$ ) is typical of the coastal areas in Arkhangelsk and Murmansk regions.

In the Asian part of the country, the zone of light wind (less than $2-3 \mathrm{~m} / \mathrm{s}$ ) covers large territories of the continental areas of Siberia and the Far East. Higher wind speed ( $4-5 \mathrm{~m} / \mathrm{s}$ ) is characteristic of some mountainous areas, coast of Lake Baikal, and valleys of large Siberian rivers (the Ob, Yenisei, Angara, and Lena). The highest long-term average annual wind speed (above $6-8 \mathrm{~m} / \mathrm{s}$ ) is in the coastal areas of Tyumen region, Krasnoyarsk Territory, Magadan region, Chukotka, Kamchatka, Sakhalin, and islands in the Arctic and Pacific Oceans.

In this study, the calculations were made for average wind speeds equal to $4-8 \mathrm{~m} / \mathrm{s}$, which corresponds to a range of 


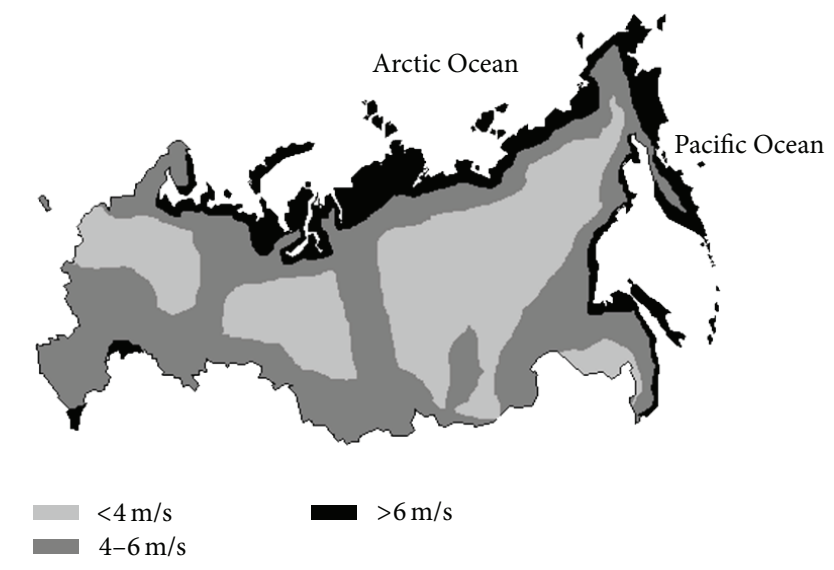

FIGURE 4: Long-term average annual wind speed $V(\mathrm{~m} / \mathrm{s})$ at a height of $10 \mathrm{~m}$ on the territory of Russia.

wind conditions from "bad" to "very good." Wind speed is distributed according to the Weibull distribution with a shape parameter $\alpha=1.5$ [1].

The relationship between wind speed and the height was described by a logarithmic dependence with a surface roughness degree $z_{0}=0.03 \mathrm{~m}$ [1]. The operating characteristic of wind turbines (power versus wind speed) is taken in accordance with the installation data of the company "Fuhrländer"; the height of a wind turbine tower for the load of $50 \mathrm{~kW}$ is $20 \mathrm{~m}$, and for the load of $1000 \mathrm{~kW}$ is $40 \mathrm{~m}$.

A retrospective analysis shows that, in the last 10-15 years, the price of diesel fuel has increased 2-3 times. Today, the minimum wholesale price of diesel fuel is in the North Caucasus ( $\$ 780 /$ toe), and the maximum is in the Republic of Yakutia (\$1600/toe). For the southern and central regions of the European part of Russia, the typical prices are \$800$\$ 1000 /$ toe, and for the northwest regions of the European Russia and northeast regions of the Far East, they equal $\$ 1100-\$ 1500 /$ toe.

In the calculations, the diesel fuel price in the range $\$ 800-\$ 1500 /$ toe was considered, which corresponds to the conditions from "relatively cheap" to "moderately expensive" diesel fuel for the autonomous power systems.

The majority of decentralized electricity consumers live in rural and urban settlements with the population from 50 to 5000 people. We consider the following consumers: (1) timeconstant power of 50 or $1000 \mathrm{~kW}$ (for the schemes in Figures 1 and 2); (2) small consumers with a variable electric load up to $50 \mathrm{~kW}$, (3) larger consumers with a load up to $1000 \mathrm{~kW}$ (for the scheme in Figure 3).

In the latter two cases, the load power was assumed to be normally distributed. The parameters of the normal law were chosen by the approximation of the annual load curve: for a load of $50 \mathrm{~kW}$ (maximum value), the average power is $20 \mathrm{~kW}$, and the standard deviation is $5 \mathrm{~kW}$, for the load of $1000 \mathrm{~kW}$, $685 \mathrm{~kW}$ and $100 \mathrm{~kW}$, respectively.

Power of the wind turbine backup energy source (diesel or fuel cells) was chosen according to the condition of power supply to consumers under any wind conditions. This allows us not to include losses from power undersupply, whose numerical value is characterized by significant uncertainty, in the objective function. To take into account the startup inertia of diesel generator and undesirable sharp change in its operation, the diesel generator was assumed to operate constantly (minimum power is $30 \%$ of the installed capacity). Fuel cells work at stationary (Figure 2) or near stationary regimes (Figure 3) because of the hydrogen store presence.

The main technical and economic indices of the power system components which determine the economic efficiency of the considered power supply schemes are the specific capital investments, fixed operating costs, efficiency, and lifetime.

Table 1 shows the corresponding indices for two power levels $(50 \mathrm{~kW}$ and $1000 \mathrm{~kW})$ and two time points, that is, the current indices (equipment is available in the market) and prospective indices. The value of power consumed (50 or $1000 \mathrm{~kW}$ ) influences technical and economic indices of the used equipment, and the degree of load unevenness influences the optimal relationship between the installed capacities as well as the operating conditions of the energy sources.

These variants are formed on the basis of the studies presented in [3, 4, 17-24]. Current indices are taken from the price lists of Russian manufacturers of equipment (with rubles converted to dollars). Among the available forecasts of changes in the indices over time, we have chosen the "moderately optimistic" ones (the most probable from the authors' viewpoint).

The main problems of hydrogen energy are the high cost of equipment and the complexity of storing and transporting hydrogen in both gas and liquid form. Hydrogen production by electrolysis on the basis of "excess" power produced by wind turbines right in the place of consumption makes this process cheaper and obviates the need to transport hydrogen. Further technological development and increase in hydrogen production and utilization will considerably improve the economic characteristics of the basic hydrogen system components, that is, electrolyzers and fuel cells [1724].

Investment in wind turbines covers the costs of assembly; construction of the foundation and tower; connection to the network; installation of inverters, control, and automation modules, which on average make up about $25 \%$ of the equipment price.

Investment in electrolyzers covers the costs of workshop construction; creation of systems for water treatment and supply, electrolyte circulation and filtration, gas collection and purification, and water condensation and cooling; the systems of automation and control (about 30\% of the equipment cost).

Cost indices of the hydrogen tank are given per unit of its capacity.

\section{Calculation Results and Their Analysis}

For the first variant (scheme in Figure 1), Figure 5 presents electricity cost values for wind turbines and diesel generators 
TABLE 1: Technical and economic characteristics of the power system components.

\begin{tabular}{|c|c|c|c|c|c|c|c|c|}
\hline \multirow[t]{2}{*}{ Component } & \multicolumn{2}{|c|}{$\begin{array}{l}\text { Specific investments } \\
(\$ / \mathrm{kW})^{*}\end{array}$} & \multicolumn{2}{|c|}{$\begin{array}{l}\text { Specific fixed costs } \\
\text { (\% of investments) }\end{array}$} & \multicolumn{2}{|c|}{ Efficiency $(\%)^{* *}$} & \multicolumn{2}{|c|}{ Lifetime (years) } \\
\hline & $50 \mathrm{~kW}$ & $1000 \mathrm{~kW}$ & $50 \mathrm{~kW}$ & $1000 \mathrm{~kW}$ & $50 \mathrm{~kW}$ & $1000 \mathrm{~kW}$ & $50 \mathrm{~kW}$ & $1000 \mathrm{~kW}$ \\
\hline \multicolumn{9}{|c|}{ Current indices } \\
\hline Diesel & 500 & 315 & 7 & 5 & 32 & 35 & 10 & 10 \\
\hline Wind turbine & 1800 & 1300 & 3 & 2 & 35 & 35 & 20 & 20 \\
\hline Electrolyzer & 3500 & 1600 & 3 & 2 & 70 & 70 & 10 & 10 \\
\hline Hydrogen tank & 880 & 570 & 1 & 1 & 95 & 95 & 10 & 10 \\
\hline Fuel cells & 5000 & 3000 & 2.5 & 2 & 40 & 40 & 4 & 5 \\
\hline \multicolumn{9}{|c|}{ Prospective indices } \\
\hline Diesel & 450 & 280 & 7 & 5 & 34 & 37 & 10 & 10 \\
\hline Wind turbine & 1600 & 1100 & 3 & 2 & 35 & 35 & 20 & 20 \\
\hline Electrolyzer & 2000 & 1000 & 3.5 & 2.5 & 77 & 77 & 20 & 20 \\
\hline Hydrogen tank & 600 & 400 & 1 & 1 & 98 & 98 & 20 & 20 \\
\hline Fuel cells & 2500 & 1500 & 3.5 & 2.5 & 60 & 60 & 10 & 10 \\
\hline
\end{tabular}

${ }^{*}$ Specific investments for the hydrogen tank are given in $\$ / \mathrm{m}^{3} ;{ }^{* *}$ efficiency of wind turbines is given for information (the calculations use wind turbine characteristics (power curve)).

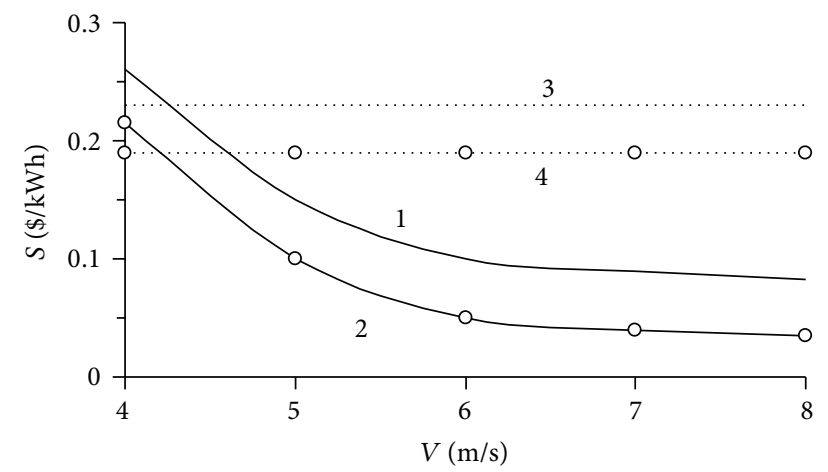

FIGURE 5: Cost of electricity generated by wind turbines and diesel generators (fuel component at a fuel price of $\$ 800 /$ toe) for the scheme in Figure 1: 1: wind turbine $(50 \mathrm{~kW}), 2$ : wind turbine $(1000 \mathrm{~kW})$, 3: diesel generator $(50 \mathrm{~kW})$, 4: diesel generator $(1000 \mathrm{~kW})$.

that are calculated by (5) with a discount rate $10 \%$ and diesel price $\$ 800 /$ toe. In this case, to estimate the economic efficiency of wind turbines, we should compare the cost of power generated by them to the fuel component of the cost of power produced by diesel generators.

Figure 5 shows that even at low long-term average annual wind speed (about $4.5 \mathrm{~m} / \mathrm{s}$ ), wind turbines are competitive with diesel generators. This is indicative of a great potential of wind turbines when used in the autonomous (decentralized) power supply systems, both in coastal areas (coasts of seas and oceans) and in some continental regions of Russia.

Figures 6 and 7 present the results of calculations for the scheme presented in Figure 2. Technical and economic indices (current and prospective) correspond to the high load power $(1000 \mathrm{~kW}$ in Table 1$)$. In the calculations, the electrolyzer power was chosen to be optimal (at high wind speed, it turned out to be equal to the installed capacity of wind turbines, and at low wind speed, less), the power of fuel cells was chosen according to the condition of constancy of generated power, and the hydrogen tank capacity was chosen according to the condition of continuous operation of fuel cells at their constant power during 120 hours.

The cost of electricity in Figure 6(a) is compared to the cost of electricity generated by diesel generators (current indices, power of $1000 \mathrm{~kW}$ in Table 1), and the hydrogen cost (Figure 6(b)) is compared to the price of diesel fuel. To provide comparability, we assume that diesel generator as well as fuel cells operates with a capacity factor equal to 1 . As we can see, according to current technical and economic indices (Table 1), the electricity generated by wind turbines and hydrogen produced by electrolyzer are more expensive than the electricity generated by diesel generator and diesel fuel, respectively.

The main component in the hydrogen cost is electrolyzer and in the electricity cost is fuel cells (Figure 7). However, in the future, the hydrogen system will become competitive, since even in the case of relatively cheap fuel and an average wind speed starting with $5-6 \mathrm{~m} / \mathrm{s}$, fuel cells generate cheaper electricity than diesel generators. This is achieved thanks to a significant decrease in specific investment in fuel cells (Table 1). Moreover, the cost of hydrogen becomes lower than the cost of diesel at higher wind speeds. This is explained by the higher efficiency of fuel cells as compared to diesel generators.

Taking into account the obtained results, the authors made calculations for the scheme in Figure 3 only for the prospective technical and economic indices (Figures 8 and 9).

Figure 8 presents the efficiency zones of energy technologies (optimal structure of the system depending on the diesel price and average wind speed). At low wind speed and low price of fuel, it is reasonable to use only diesel generator to supply power to consumers. When the fuel price and wind 


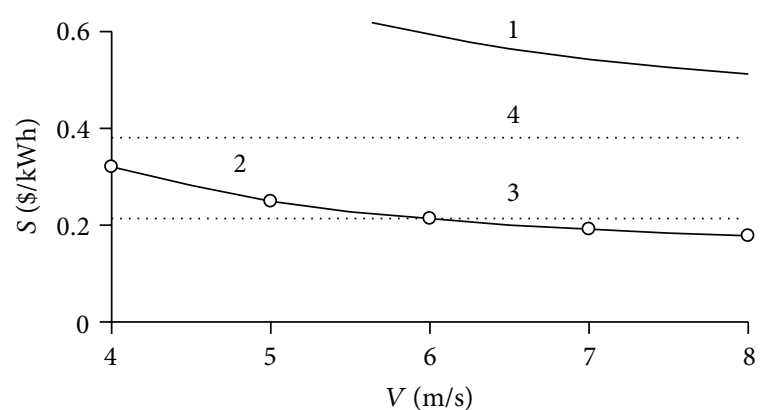

(a)

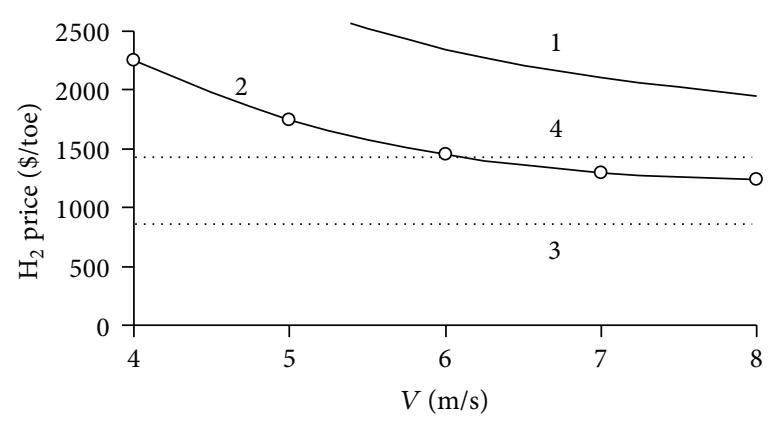

(b)

FIGURE 6: Cost of electricity generated by fuel cells (a) and cost of hydrogen supplied from the hydrogen tank (b) for the scheme in Figure 2: 1: current indices of the system components; 2 : prospective indices; 3: electricity from diesel generator at a fuel price of $\$ 800 /$ toe (a) and fuel price of $\$ 800 /$ toe $(b) ; 4$ : the same, fuel price is $\$ 1400 /$ toe.

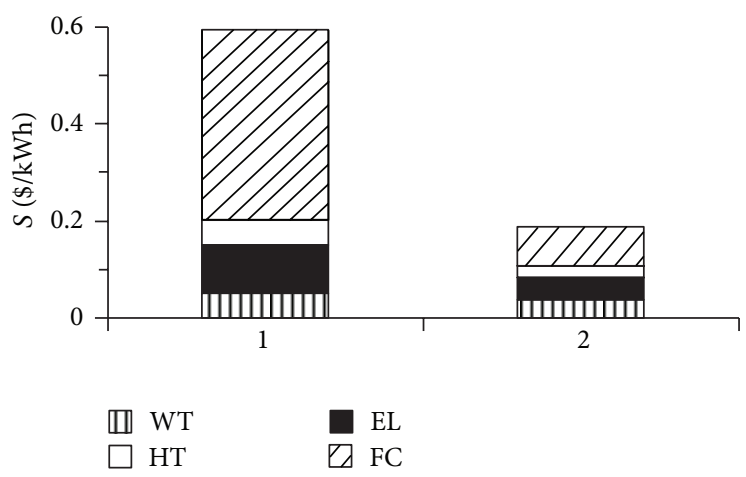

(a)

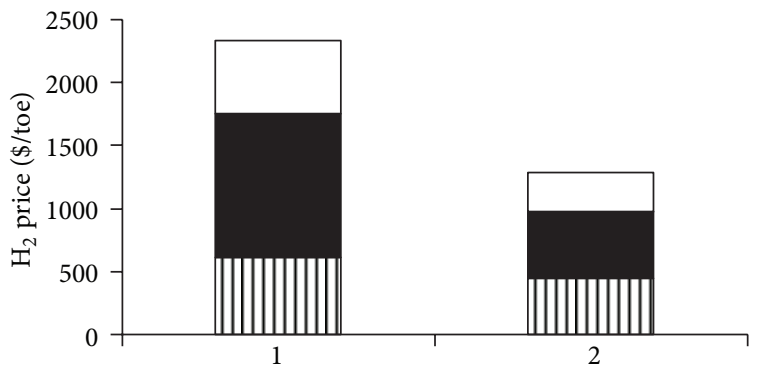

Ш WT $\square$ HT

$\square \mathrm{EL}$

(b)

FIGURE 7: Structure of costs of electricity (a) and hydrogen (b) production at wind speed $6 \mathrm{~m} / \mathrm{s}$ for the scheme in Figure 2: 1: current indices of the system components; 2: prospective indices. WT are the wind turbines, EL is the electrolyzer; HT is the hydrogen tank, and FC are the fuel cells.

speed increase, first it becomes more economical to use a wind-diesel system and then wind turbines with a hydrogen system. In the latter case, according to the optimization results, diesel generator is excluded from the system. Cost effectiveness of wind turbines and fuel cells at a load of $1000 \mathrm{~kW}$ is provided at lower wind speed and lower diesel price than for a load of $50 \mathrm{~kW}$, since the specific indices of larger energy sources are better. When the load equals $1000 \mathrm{~kW}$, the application of a diesel generator alone in the considered region of parameters turns out to be inefficient.

Zones of technological efficiency allow us to determine the best structure of the power supply system for the given conditions. Moreover, we should know what economic effect can be achieved by applying the optimal structure because only if the effect is sufficient, it makes sense to complicate the system by adding extra components. The corresponding data are presented in Figure 9. As we can see, the size of the achieved effect is quite significant.

For example, with the load of $1000 \mathrm{~kW}$ and the average wind speed of $6 \mathrm{~m} / \mathrm{s}$, the construction of wind turbines in addition to diesel generator makes it possible to decrease the electricity cost from 27 to 20 cent/kWh and the replacement of the diesel generator by an electrochemical unit to $15 \mathrm{cent} / \mathrm{kWh}$. Thus, the introduction of a wind-hydrogen system will allow us to halve the costs of electricity production as compared to power supply from diesel generator alone.

\section{Conclusion}

The paper presents an analysis of the economic efficiency of harnessing wind energy in the autonomous power systems of Russia. The wind turbines are shown to be competitive in many considered variants (groups of consumers, placement areas, and climatic and meteorological conditions).

At the current prices of fossil (diesel) fuel, the application of wind/diesel systems is efficient even if the long-term average annual wind speed on the wind turbine site is relatively low (about $4.5 \mathrm{~m} / \mathrm{s}$ ). In the regions with a long-term average annual wind speed higher than $5 \mathrm{~m} / \mathrm{s}$, the application of wind turbines can reduce the price of the generated electricity by $50 \%$ or more (as compared to the use of diesel generators alone). 


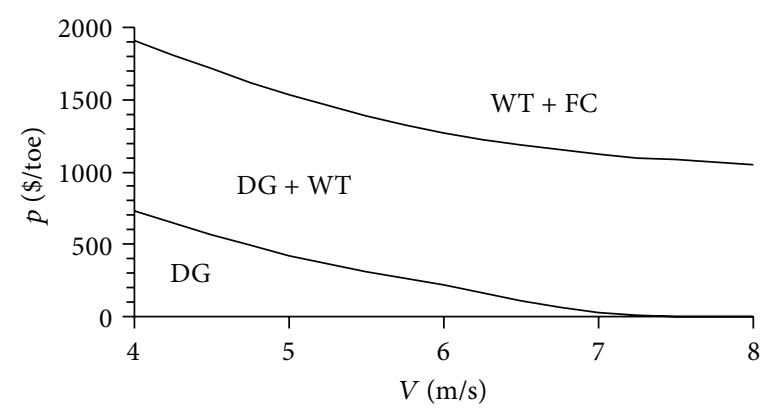

(a)

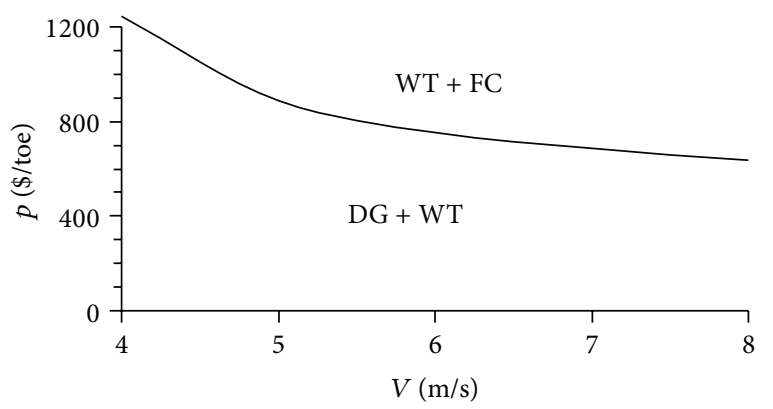

(b)

FIGURE 8: Zones of technological efficiency with the load power of $50 \mathrm{~kW}(\mathrm{a})$ and $1000 \mathrm{~kW}$ (b) and prospective indices of electrolyzer, hydrogen tank, and fuel cells for the scheme in Figure 3. $V$ is the average wind speed at a height of $10 \mathrm{~m}, p$ is the diesel price, WT are the wind turbines, DG is the diesel generator, and FC are the fuel cells.

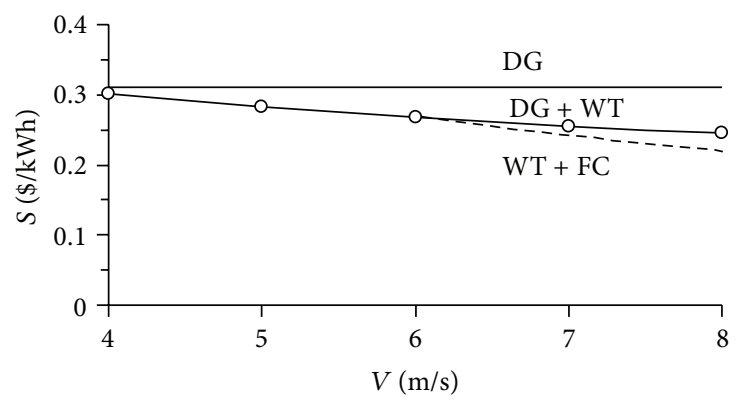

(a)

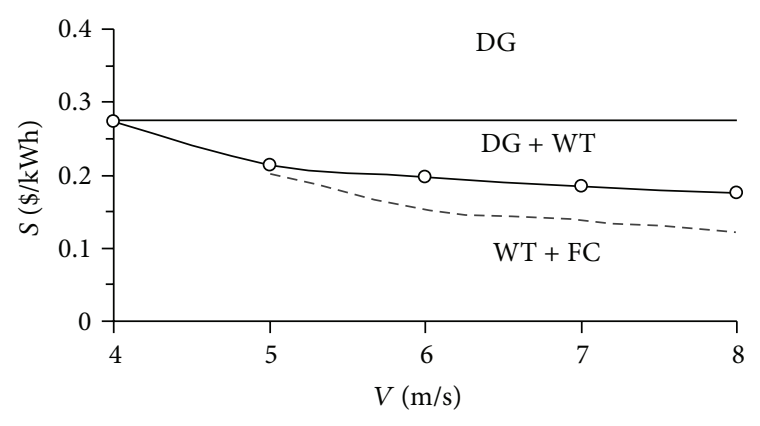

(b)

FIGURE 9: Electricity cost for the scheme in Figure 3 at a fuel price of $\$ 1100 /$ toe and with the load power of $50 \mathrm{~kW}$ (a) and $1000 \mathrm{~kW}$ (b) and prospective indices of electrolyzers, hydrogen tanks, and fuel cells. $V$ is the average wind speed at a height of $10 \mathrm{~m}, p$ is the diesel price, DG is the diesel generator, WT are the wind turbines, and FC are the fuel cells.

During the periods of strong wind, some amount of power generated by wind turbines turns out to be redundant. Therefore, it becomes possible to use this power for hydrogen production by electrolysis and its subsequent electrochemical transformation into electricity. Under certain conditions, the introduction of subsystem for hydrogen production, storage, and use for energy purposes to the wind/diesel system can decrease diesel consumption (or even completely exclude diesel generators from the system) and reduce the costs of electricity production.

The study considered the possibility of storing energy in the form of hydrogen in the autonomous wind/diesel/ hydrogen power systems that include a diesel generator, electrolyzer, hydrogen tank, and fuel cells. The authors determined the zones of economic efficiency in the system depending on the load power, fuel price, and long-term average annual wind speed.

Technical and economic characteristics of the equipment, which is now available in the market, still do not allow the hydrogen system (electrolyzer, hydrogen tank, and fuel cells) to become competitive with diesel or wind-diesel power plants. However, the indices projected for the nearest future (an approximately twofold decrease in specific capital investment in fuel cells against the current level) make the hydrogen system economically efficient at the fuel prices typical of the autonomous power systems ( $\$ 800-\$ 1400 /$ toe) and the average annual wind speed starting with $5-6 \mathrm{~m} / \mathrm{s}$. Application of the system for the hydrogen production and use for energy purposes will considerably reduce (more than by $50 \%$ ) the costs of power supply to consumers.

\section{Nomenclature}

$b$ : Specific fuel consumption (toe/kWh)

$d$ : Annual discount rate

$E(\tau)$ : Cash flow (\$/year)

CF: Capacity factor

CRF: Capital recovery factor (1/year)

$f(v)$ : Wind turbine power curve

$h$ : Annual number of utilization hours (hours/year)

$H: \quad 8760$ hours/year

$k$ : $\quad$ Specific investments $(\$ / \mathrm{kW})$

$K: \quad$ Investments (\$)

$L: \quad$ Load $(\mathrm{kW})$

NPV: Net present value (\$)

$p_{e}: \quad$ Electricity price $(\$ / \mathrm{kWh})$

$p_{f}: \quad$ Fuel price $(\$ /$ toe $)$

$P$ : $\quad$ Power $(\mathrm{kW})$ 


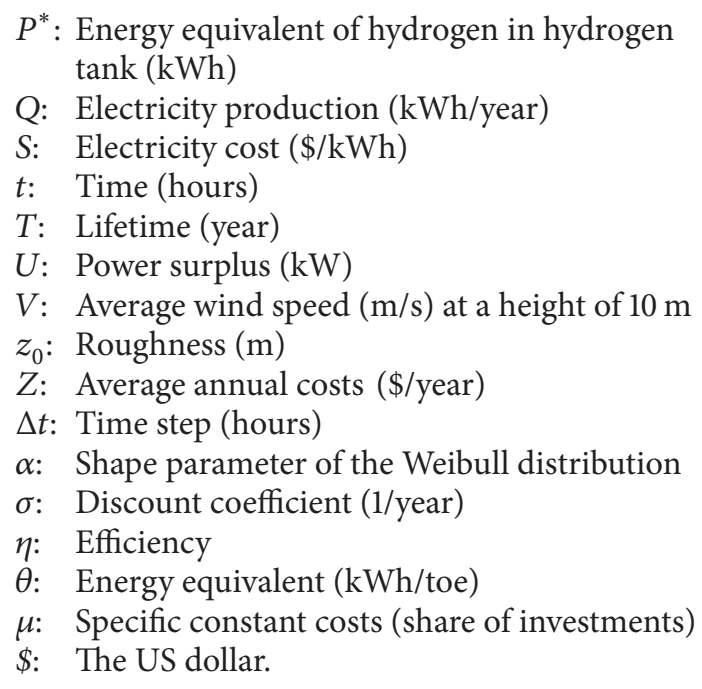

Indices

$i$ : $\quad$ Type of power plant

max: Maximum

min: Minimum.

\section{Abbreviations}

DG: Diesel generator

DL: Dump load

EL: Electrolyzer

FC: Fuel cells

HT: Hydrogen tank

O\&M: Operation and maintenance

RES: Renewable energy sources

WT: Wind turbines.

\section{Acknowledgment}

The study was supported by the Ministry of Education and Science of the Russian Federation (State Contract no. 07.514.11.4099).

\section{References}

[1] O. V. Marchenko and S. V. Solomin, "Efficiency of wind energy utilization for electricity and heat supply in northern regions of Russia," Renewable Energy, vol. 29, no. 11, pp. 1793-1809, 2004.

[2] O. V. Marchenko and S. V. Solomin, "Assessment of the economic and environmental efficiency of solar heat supply in Russia," Thermal Engineering, vol. 48, no. 11, pp. 928-931, 2001.

[3] O. V. Marchenko and S. V. Solomin, "The analysis of hydrogen production efficiency with application of wind turbines and its use in autonomous energy system," International Scientific Journal for Alternative Energy and Ecology, vol. 3, no. 47, pp. 112118, 2007.

[4] O. V. Marchenko and S. V. Solomin, "The analysis of economic effectiveness of renewable energy sources in dezentralized energy systems," International Scientific Journal for Alternative Energy and Ecology, vol. 5, no. 73, pp. 78-84, 2009.
[5] O. V. Marchenko and S. V. Solomin, "The investigation of economic efficiency of wind turbines in dezentralized energy systems," International Scientific Journal for Alternative Energy and Ecology, vol. 1, no. 81, pp. 126-131, 2010.

[6] O. V. Marchenko, "Mathematical modeling and economic efficiency assessment of autonomous energy system with production and storage of secondary energy carriers," International Journal of Low-Carbon Technologies, vol. 5, no. 4, pp. 250-255, 2010.

[7] O. V. Marchenko, "Mathematical model of energy system with renewable energy sources," Izvestia RAN. Energetika, no. 3, pp. 154-161, 2006 (Russian).

[8] L. S. Belyaev, S. P. Filippov, O. V. Marchenko et al., World Energy and Transition to Sustainable Development, Kluwer Academic Publishers, London, UK, 2002.

[9] L. S. Belyaev, O. V. Marchenko, and S. V. Solomin, "Study of long-term trends in the development of renewable energy sources," Perspectives in Energy, vol. 11, no. 1, pp. 9-17, 2007.

[10] O. V. Marchenko and S. V. Solomin, "System studies for analyzing the efficiency of renewable energy sources," Thermal Engineering, vol. 57, no. 11, pp. 919-924, 2010.

[11] L. S. Belyaev, O. V. Marchenko, and S. V. Solomin, "A study of wind energy contribution to global climate change mitigation," International Journal of Energy Technology and Policy, vol. 3, no. 4, pp. 324-341, 2005.

[12] L. S. Belyaev, O. V. Marchenko, S. P. Filippov, and S. V. Solomin, "Studies on competitiveness of space and terrestrial solar power plants using global energy model," International Journal of Global Energy Issues, vol. 25, no. 1-2, pp. 94-108, 2006.

[13] Global Wind Report, Annual Market update 2011, Global Wind Energy Council, Brussels, Belgium, 2012.

[14] World Wind Energy Report 2010, WWEA, Bonn, Germany, 2010.

[15] O. V. Marchenko, "Mathematical modelling of electricity market with renewable energy sources," Renewable Energy, vol. 32, no. 6, pp. 976-990, 2007.

[16] O. V. Marchenko, "Modeling of a green certificate market," Renewable Energy, vol. 33, no. 8, pp. 1953-1958, 2008.

[17] S. Thomas and F. Lomax, Low-Cost Hydrogen Distributed Production Systems, 2006 DOE Hydrogen Program Review, H2Gen Innovations, 2006.

[18] D. Rastler, Status, Trends and Market Forecast for Stationary Fuel Cell, EPRI, Ohio, USA, 2005

[19] K.-A. Adamson, Fuel Cell Today Market Survey: Large Stationary Applications, London, UK, 2006.

[20] J. Cotrell, W. Pratt et al., "Modeling the feasibility of using fuel cells and hydrogen internal combustion engines in remote renewable energy systems," NREL/TP 500-34648, Golden, 2003.

[21] M. Beccali, S. Brunone, M. Cellura, and V. Franzitta, "Energy, economic and environmental analysis on RET-hydrogen systems in residential buildings," Renewable Energy, vol. 33, no. 3, pp. 366-382, 2008.

[22] R. S. Garcia and D. Weisser, "A wind-diesel system with hydrogen storage: joint optimisation of design and dispatch," Renewable Energy, vol. 31, no. 14, pp. 2296-2320, 2006.

[23] D. B. Nelson, M. H. Nehrir, and C. Wang, "Unit sizing and cost analysis of stand-alone hybrid wind/PV/fuel cell power generation systems," Renewable Energy, vol. 31, no. 10, pp. 16411656, 2006. 
[24] B. E. Türkay and A. Y. Telli, "Economic analysis of stand alone and grid connected hybrid energy systems," Renewable Energy, vol. 36, no. 7, pp. 1931-1943, 2011. 


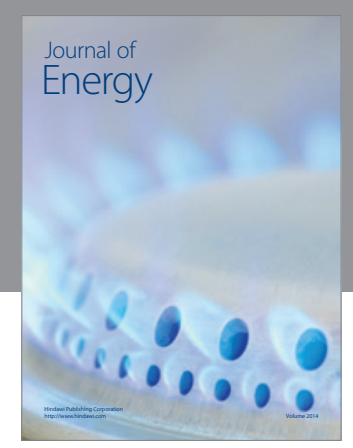

Journal of

Industrial Engineering
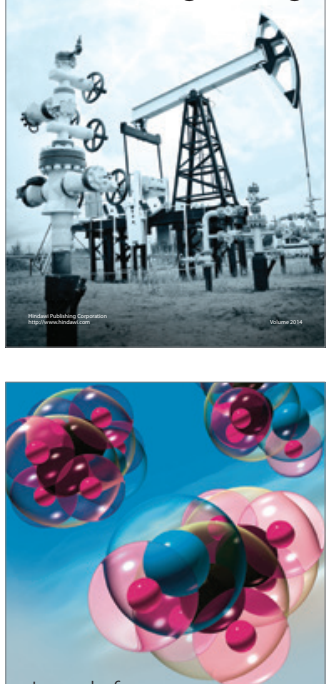

Fuels
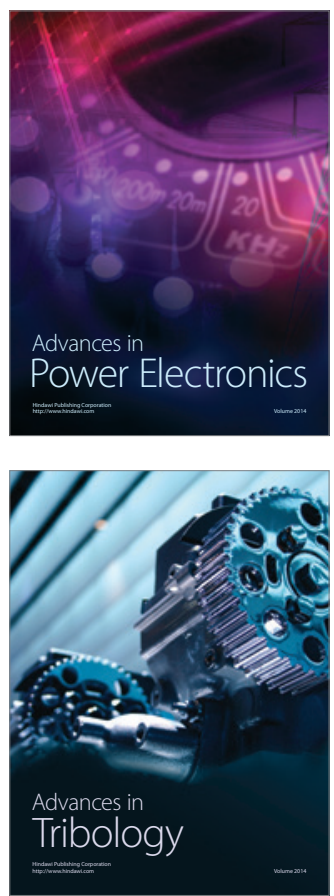

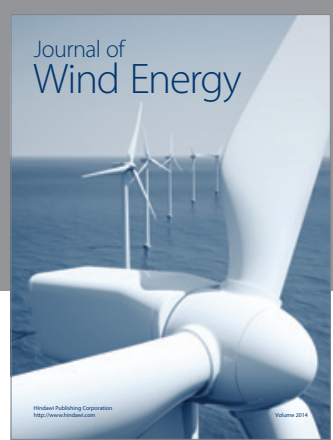

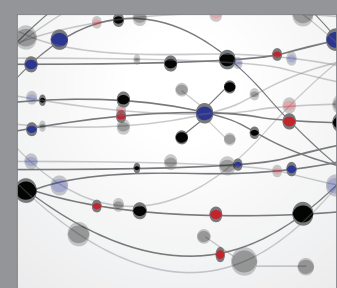

The Scientific World Journal

Submit your manuscripts at http://www.hindawi.com

Journal of

Structures
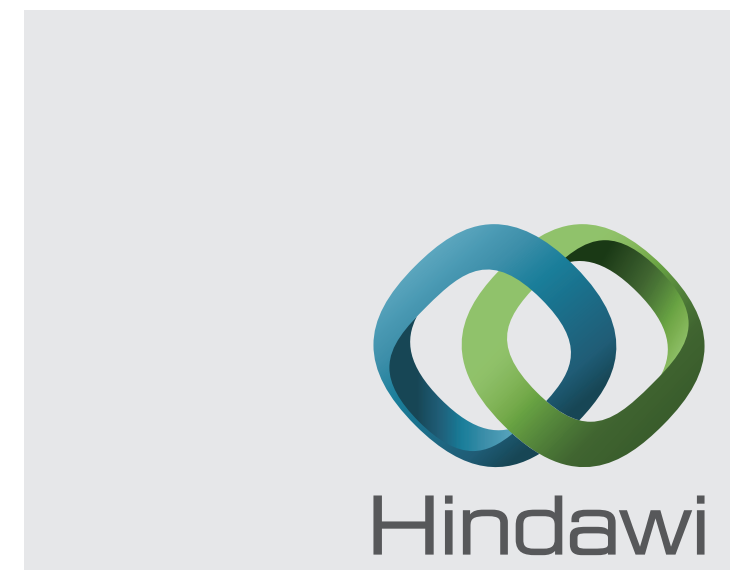

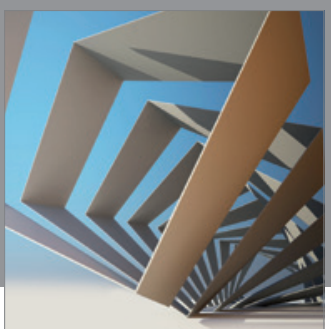

Rotating

Machinery
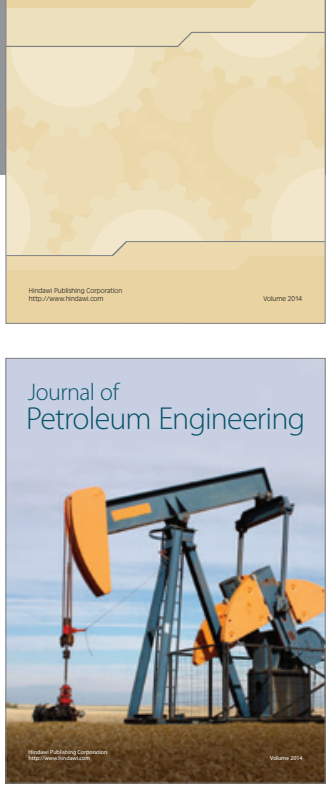

Journal of

Solar Energy
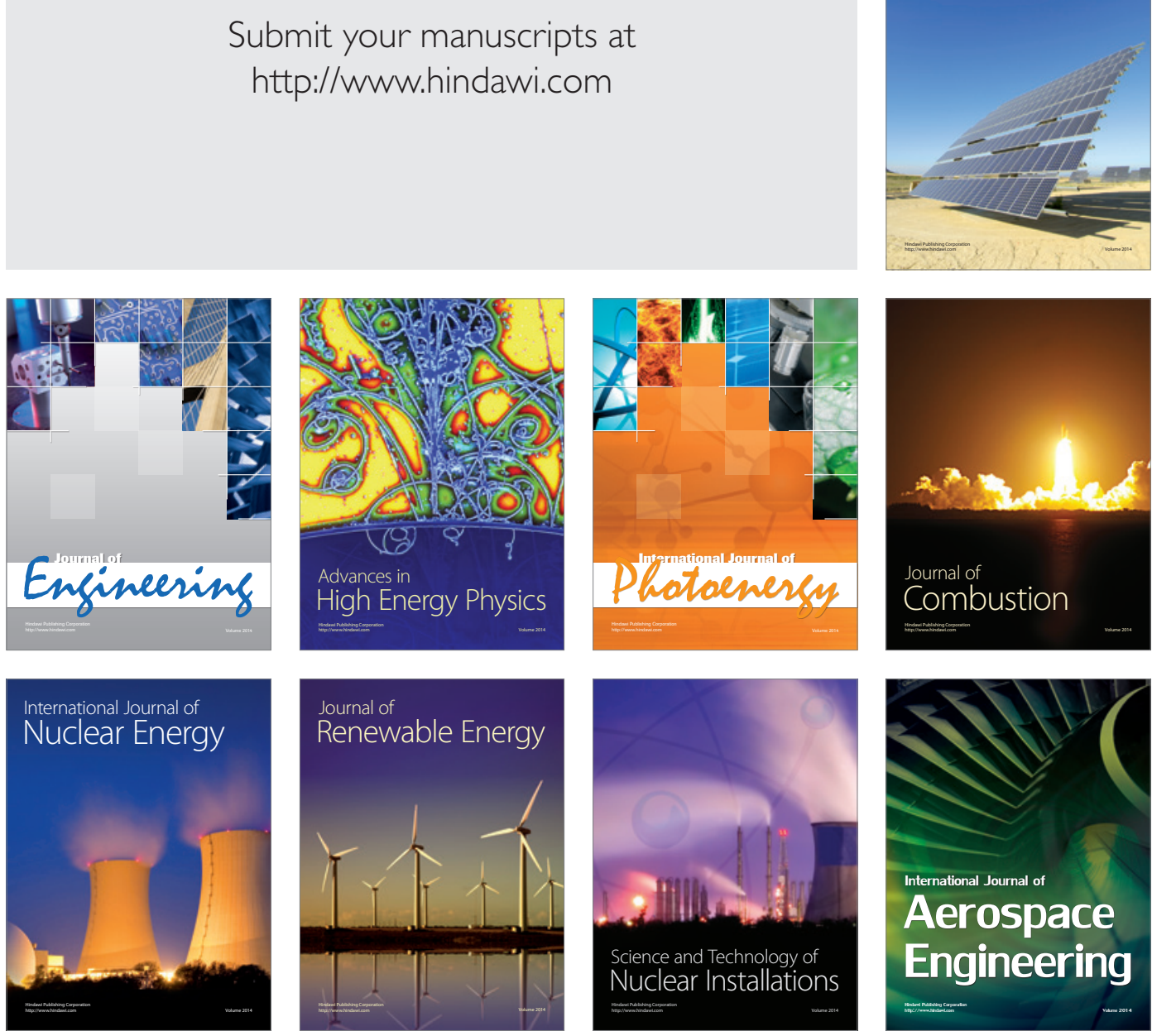